start to be made on collaboration in such fields as industrial standards, company law and patents which the Council of Europe has begun to examine. The European Institute of Technology proposed by the Prime Minister in November was described as an "organization that would provide an independent centre of analysis available to governments and industries on industrial structures, problems and future developments". It would provide a forum for technological cxchanges, and by working in close collabora. tion with the EEC commission it could "play a major role in accelerating the achievement of a European technological community-a community which is essential if Europe's potentials are to be realized". But those who hoped that Mr Benn would finally disclose exactly what is in the Prime Minister's mind were disappointod. The European Institute of Technology remains a nebulous idea, splendid for injecting life into otherwise familiar speeches, but not apparently the subject of much serious study.

\section{Unequal Trade}

WI'H the worsening of relations between rich and poor countries as a result of wars in the Middle East and in Vietnam and racial tension in many countries, the meeting of the United Nations Conference on Trade and Development (UNCTAD) which is taking place in New Delhi will not be all plain sailing. The last meeting in Geneva in 1964 was an acknowledged flop, and hopes for the New Delhi meeting are not high. Too many countries, Britain included, have gone to the meeting without a clear policy.

UNCTAD-defined in the most recent annual review of the Overseas Development Institute (ODI, 12s.6d.) as "a forum for redressing the balance of the world's economic system in favour of the developing countries" - has not been a triumphant success in the past few years. Although one of its aims is to increase the production and value of commodities on which most developing countries rely, the price of commodities continues to fall. Increases in production or in productivity tend inevitably to be reflected by a decline in the prices paid for the commodities, so that the processes by which developed countries advance themselves tend to do the opposite for underdeveloped countries. UNCTAD also cherishes a hope of establishing aid to developing countries at the rate of 1 per cent of the GNP of developed countries, and of promoting tourism and regional co-operation between developing countries. But the chances of increasing aid at the moment are slim indeed-the British aid programme is to be fixed at the present ceiling of $£ 205$ million per year, despite devaluation, which means that the real value of the aid which Britain dispenses has fallen by between 8 and 11 per cent. This has happened after an actual cut of $£ 20$ million announced at the end of 1966 , so that the value of British aid to developing countries has fallen steadily for the past two years. In the circumstances, it would perhaps have been unreasonable to expect anything else, but it is hard for developing countries to feel that Britain's economic difficulties, alarming as they are, are anything like as serious as their own.

The annual review from the ODI suggests ways in which developing countries can make the best of a bad situation. It would not be helpful, the report argues, if the developing countries use the present UNCTAD meeting to attempt to force concessions from developed countries. UNCTAD, the authors of the report say, must work through consensus-if the proceedings are based on bargaining from strength, it will be impossible to get the system changed for the simple reason that bargaining from strength has produced the very system which is under attack. The UNCTAD secretariat, headed by Dr Rául Prebish, has prepared a detailed analysis of the present situation, together with a series of proposals for action, but these have been treated with scepticism by some of the developed countries. The ODI report suggests that detailed argument about the way the case has been presented should not be allowed to obscure the basic issue-that the present system for operating world trade is biased against the developing countries. UNCTAD, the report concludes, must devote itself to changing the economic system, not to trying to secure concessions within the existing system.

Whether the developing countries accept this timely advice remains to be seen. There is little doubt, however, that without a new stimulus the world aid programme runs the risk of coming to a halt through political apathy in the developed countries. This is depressing, and in this context the occasional success stories are very refreshing. Pakistan and Kenya are likely to be quoted frequently at the UNCTAD meeting as examples of what can be done.

\section{Reducing the Risks}

THE opening of the advanced Nuffield Transplantation Surgery Unit on January 31 by Sir Peter Medawar marks an important step forward in this extremely complex field. The Nuffield Foundation provided $£ 230,000$ towards the cost of the unit, which is at the Western General Hospital in Edinburgh.

According to Professor M. F. A. Woodruff, who is the director, the new unit has been designed for the treatment of patients who run a particular risk of infection because of having received immuno-suppressive agents. Three main categorics of patients will be admitted; first, those patients receiving organ transplants and who are receiving immuno-suppressive drugs; second, patients with auto-immune diseases also receiving these drugs; and, third, certain types of cancer patients who have reduced resistance to infectious agents. The unit will, however, also be available to patients who have been accidentally exposed to radiation.

There are six patient rooms and two operating theatres in the unit. These work on a complicated system of ventilation with sterilized air under pressure which will prevent any cross-infection. All materials entering the unit will be sterile and wrapped, and communication between patients and visitors will be through glass and using microphones. The first patients will be those receiving kidney grafts.

\section{Waiting, Not Yet Seeing}

THE mceting last week in Geneva of the Council of the European Molecular Biology Organization (EMBO) seems to have been a mixed success. The proposal for a central laboratory was presented by EMBO but not formally discussed-that will not happen until 